\title{
Justyna Góral
}

Instytut Ekonomiki Rolnictwa i Gospodarki Żywnościowej - Państwowy Instytut Badawczy

\section{Instrumenty wspierania gospodarstw rolniczych w Polsce}

Kody JEL: H2, Q1, P2

Słowa kluczowe: polskie gospodarstwa rolnicze, pomoc krajowa, Wspólna Polityka Rolna, interwencjonizm

Streszczenie. W pracy przeanalizowano aktualne formy pomocy kierowanej do gospodarstw rolniczych z budżetu krajowego i unijnego. Pokazano także wiele udogodnień prawnych, które w połączeniu z pomocą finansową tworzą kompleksowy pakiet wsparcia rolnictwa.

\section{Wprowadzenie}

Rolnictwo to pierwotny dział gospodarki, dlatego jest uwzględniane we wszystkich systemach ekonomicznych i politycznych, ponieważ jest charakterystyczne dla otoczenia człowieka we wszystkich regionach i strefach klimatycznych. Aktywność gospodarczą rolnictwa determinują uwarunkowania tworzone przez siły natury. Zdaniem Sobieckiego (2015) to powoduje, że mamy do czynienia $z$ wieloma formami rolnictwa, różniącymi się strukturą czynników produkcji, rodzajem wytwarzanych produktów, efektywnością, warunkami społecznymi, politycznymi, itd.

Według belgijskiego ekonomisty rolnego Van Huylenbroecka (2007) rolnictwo spełnia cztery rodzaje funkcji pozakomercyjnych: 
1. Funkcje zielone: zarządzanie zasobami ziemi w celu utrzymania jej wartościowych właściwości, stwarzanie warunków dla dziko żyjących zwierząt i roślin, ochrona dobrostanu zwierząt, utrzymanie bioróżnorodności i poprawa obiegu substancji chemicznych w systemach produkcji rolnej.

2. Funkcje błękitne: zarządzanie zasobami wodnymi, poprawa jakości wód, zapobieganie powodziom, wytwarzanie energii wodnej i wiatrowej.

3. Funkcje żółte: utrzymywanie spójności i żywotności obszarów wiejskich, podtrzymywanie i wzbogacanie tradycji kulturalnej oraz tożsamości wsi i regionów, rozwój agroturystyki i myślistwa.

4. Funkcje białe: zapewnianie bezpieczeństwa żywnościowego i produkcja zdrowej żywności (food security and food safety).

Rosnąca konkurencja na globalnym rynku, a z drugiej strony wymogi związane z ochroną środowiska czy dobrostanem zwierząt, powodują rosnącą presję poprawy konkurencyjności polskich gospodarstw oraz elastycznych dostosowań do otoczenia. W tym kontekście znaczną rolę odgrywa właściwie ukierunkowana pomoc publiczna mająca skłaniać jej beneficjentów do poprawy efektywności funkcjonowania przy jednoczesnym uwzględnianiu stanu dóbr publicznych. Interwencjonizm państwowy to polityka aktywnego oddziaływania państwa na przebieg procesów gospodarczych. Ingerencja taka najpełniej zaznacza się w obszarze rolnym, stąd celem artykułu było przybliżenie jej form na przykładzie Polski.

\section{Interwencjonizm rolny - przyczyny i uzasadnienie}

Początków znaczącego protekcjonizmu doszukać się można w epoce merkantylizmu (druga połowa XVI w.), kiedy to wielkie odkrycia geograficzne i postęp gospodarczy ożywiły rozwój przemysłu i wymianę handlową. Namiastką interwencjonizmu była polityka celna. Za twórcę polityki celnej, wykorzystującej finansowe i pozafinansowe narzędzia w obronie gospodarki rodzimej, uważa się J.B. Colberta (ministra finansów Francji w latach 16651683). Wybuch światowego kryzysu gospodarczego w 1873 roku zaostrzył walkę konkurencyjną przede wszystkim na światowych rynkach artykułów rolnych. Kryzys agrarny objął większość krajów gospodarczo rozwiniętych, w wyniku czego nastąpił nawrót protekcjonizmu państwowego (neoprotekcjonizm). W 1890 roku Stany Zjednoczone wprowadziły tzw. taryfę McKinleya, podwyższając poziom ceł z 24-30\% do 50\%, które w 1897 roku podwyższono do $57 \%$. W handlu zagranicznym protekcjonizm był podstawą oddziaływania władz publicznych na sektor rolny aż do lat trzydziestych XX wieku, kiedy to Wielki Kryzys gospodarczy skutkował wzrostem ekonomicznej roli państwa na rynku wewnętrznym. Zwarty system interwencji gospodarczej państwa najwcześniej został wprowadzony w USA i w euro- 
pejskich państwach faszystowskich. Integracja i ujednolicenie systemów interwencji rolnej w rozwiniętej gospodarczo Europie nastąpily wraz z utworzeniem Europejskiej Wspólnoty Gospodarczej (EWG). Interwencjonizm rolny EWG osiągnął najszerszy zakres subsydiowania pod koniec lat osiemdziesiątych XX wieku, zaś w latach dziewięćdziesiątych przeprowadzono gruntowną reformę polityki rolnej. Zdaniem Wilkina (2002), uruchomienie polityki sektorowej to stworzenie określonemu działowi gospodarki uprzywilejowanych warunków rozwoju wskutek oddziaływania grup interesu bądź wykazania, że istnieją ku temu ważne przesłanki ekonomiczne (np. zjawisko zawodności rynku - market failure). W Europie zniszczonej działaniami wojennymi panowała powszechna zgoda na traktowanie sektora rolnego jako szczególnego działu gospodarki (Wilkin, 2009).

Teoretyczne podstawy współczesnego interwencjonizmu państwowego stworzył angielski ekonomista J.M. Keynes (1883-1946) argumentując jego potrzebę przez negację założeń ekonomii neoklasycznej o doskonałości rynku. Twórcy współczesnych teorii ekonomicznych nie kwestionują w większości konieczności stosowania interwencjonizmu państwowego tam, gdzie mechanizm wolnego rynku nie może sprawnie funkcjonować (Czyżewski, 2003).

W opinii Spychalskiego (2008), interwencjonizm oznacza świadomą i celową działalność władzy publicznej (centralnej i samorządowej) ograniczającą niedoskonałości mechanizmu rynkowego i wspierającą procesy rozwojowe $\mathrm{w}$ gospodarce. Zwykle przyjmuje on formułę polityki ekonomicznej, której instrumenty kształtują zachowania producentów i konsumentów, jak również wyznaczają pewne ramy ich aktywności. Szczególnie istotne jest oddziaływanie polityki gospodarczej wobec rolnictwa i obszarów wiejskich, gdzie mechanizm rynkowy nie gwarantuje odpowiedniej alokacji zasobów, a specyfika produkcji wymaga wsparcia instytucjonalnego. Ponadto, współczesne rolnictwo staje się kluczowym konserwatorem zasobów przyrodniczych, co uzasadnia transfer części dochodu społecznego do właścicieli gospodarstw. Interwencjonizm w rolnictwie jest trwałą cechą procesu gospodarczego, umożliwiającą wypełnianie przez rolnictwo wszystkich swoich funkcji - produkcyjno-wyżywieniowej, ekonomicznej, ekologicznej, społecznej i kulturowej. Stiglitz (1987) wskazuje na następujące przyczyny interwencji państwa w rolnictwie: niekompletność i niedoskonałość rynków związanych z rolnictwem, konieczność i przydatność dostarczania rolnictwu dóbr o charakterze publicznym, występowanie zjawiska kosztów i efektów 
zewnętrznych, niedoskonałość informacji oraz problemy dochodowe rolnictwa ${ }^{1}$.

Realizacja celów polityki interwencjonizmu państwowego w rolnictwie odbywa się przez stosowanie wielu instrumentów ekonomicznych i administracyjno-prawnych, ograniczających w sposób pośredni i bezpośredni mechanizm wolnej konkurencji. Można je podzielić na rynkowe i pozarynkowe oraz wydzielić protekcjonizm wewnętrzny i zewnętrzny. W takim zamyśle została stworzona w 1957 roku Wspólna Polityka Rolna Unii Europejskiej. W podobnym celu zresztą urzędnicy prezydenta H.C. Hoovera (1929-1933) i przede wszystkim F.D. Roosevelta (1933-1945) wprowadzili wiele programów pomocy państwowej dla amerykańskiego rolnictwa ${ }^{2}$, które wraz z upływem lat rozrastały się.

Zdaniem Sobieckiego (2015), instrumenty polityki rolnej miały na celu złagodzenie fluktuacji cenowych w rolnictwie i podniesienie dochodów rolniczych do poziomu, który uznawano za „parytetowy”. Formy interwencji w Europie, Stanach Zjednoczonych i w wielu innych krajach wysoko rozwiniętych, były podobne. Podstawową rolę odgrywały tzw. ceny instytucjonalne (wskaźnikowe, interwencyjne, minimalne, ceny progu), instrumenty polityki handlowej (cła, opłaty wyrównawcze, kontyngenty, subsydia eksportowe), zakupy interwencyjne, gromadzenie i upłynnianie rezerw produktów rolnych, a także bezpośrednie wspieranie dochodów rolniczych (kredyt subsydiowany, płatności kompensacyjne).

Należy jednak dodać, że nadmierny interwencjonizm państwowy doprowadził do wielu niekorzystnych zjawisk, choćby takich jak: ograniczenie możliwości rozwoju krajów biednych i pojawienie się znacznych nadwyżek żywności w Unii. W świetle przeglądu literatury można sformułować następującą listę negatywnych skutków subsydiowania rolnictwa:

- oburzenie części społeczeństwa, która uznaje subsydia za działanie nieuczciwe (niszczące naturalną przedsiębiorczość i konkurencyjność),

- niezadowolenie konsumentów żywności, którzy muszą płacić wyższe ceny za produkty rolne,

\footnotetext{
${ }^{1}$ Konieczność interwencji w rolnictwie można też uzasadnić tzw. teorią siły przeciwnej. Według Galbraitha (1991), rolnictwo nie wytworzyło siły zdolnej do przeciwstawienia się potędze rynku. Państwo ma tę siłę tworzyć.

${ }^{2}$ Obecnie głównym aktem określającym politykę rządu USA są tzw. ustawy rolnicze na kolejne lata (obecnie Farm Bill na lata 2014-2018). Ustawy rolnicze (wraz z budżetami) można przyrównać do WPR UE. Głównymi narzędziami wspierania rolnictwa, w myśl ustaw rolnych, są: dotacje bezpośrednie do produkcji, dotacje pośrednie (odłogowanie ziemi czy zabezpieczenie krajobrazu naturalnego), system zarządzania ryzykiem (gwarancja ceny, kontraktacja plonów) oraz dopłaty do eksportu.
} 
- zachęcenie do nadprodukcji,

- przejmowanie dużej części dotacji przez otoczenie rolnictwa (tzw. wyciek wsparcia),

- zachęcenie do nadmiernej eksploatacji środowiska naturalnego (internalizacja negatywnych efektów zewnętrznych),

- pojawienie się wielu niedorzecznych wytycznych (rozporządzeń) oraz nadmierna rozbudowa biurokracji (Duczkowska-Małysz, 2013; Rembisz, 2010; Żmija, 2011).

Warto także dodać, że kraje należące do Grupy Cairns ${ }^{3}$ konsekwentnie dążą do liberalizacji światowego handlu i swobody obrotu produktami rolnymi opartymi na mechanizmach rynkowych (bez ich subsydiowania). Aktywną rolę odgrywa tu Nowa Zelandia.

Trzeba też zauważyć, że WPR należy do najbardziej kosztownych rodzajów polityki UE, co jest powodem krytyki ze strony konsumentów z uwagi na drogą żywność. Poszerzenie UE-15 o nowe kraje tzw. UE-12 uświadomiło konsumentom starej Unii, że produkty z Europy ŚrodkowoWschodniej są tańsze i zazwyczaj lepszej jakości (mniejszy udział środków chemicznych $\mathrm{w}$ produkcji). Ponadto bezpośrednie wspieranie produkcji rolnej spowodowało powstanie ogromnych nadwyżek żywności w latach 70. i 80. XX wieku. Obecnie dotacje są powiązane z powierzchnią użytków rolnych (decoupling), co ma zapobiegać nadmiernej i szkodliwej dla środowiska (i konsumentów) intensyfikacji produkcji.

Ponadto, według szacunków OECD (2013) do 80\% transferów finansowych kierowanych do sektora rolnego, było przechwytywanych przez producentów środków produkcji dla rolnictwa oraz sektory przetwórstwa i handlu. Poza tym część tych transferów trafiała do właścicieli ziemi, niezajmujących się bezpośrednio produkcją rolniczą (wyższe czynsze). Zatem efektywność tego wsparcia była niska. Obecnie pojawiła się definicja tzw. rolnika aktywnego zawodowo, który wniosek o dotacje musi udokumentować potwierdzeniem prowadzenia produkcji rolnej.

\section{Pomoc publiczna w polskim rolnictwie}

W pierwszych miesiącach transformacji w Polsce nie było żadnej polityki rolnej ani wsparcia dla rolnictwa. Zdaniem Wilkina (2015), pojawiła się wówczas próżnia systemowa i regulacyjna. W 1990 roku całkowicie otworzono granice. Polska była wówczas najbardziej otwartym krajem Europy. Wszystko to razem złożyło się na bardzo trudną sytuację, w jakiej znalazły

\footnotetext{
3 Koalicja krajów opowiadających się za liberalizacją handlu artykułami rolnymi (www.cairnsgroup.org).
} 
się wieś i rolnictwo. Dopiero po powołaniu agencji, w tym Agencji Własności Rolnej Skarbu Państwa, zaczęto nieco porządkować sytuację. Polska polityka rolna po 1990 roku, gdy wprowadzono system gospodarki indywidualistycznej z dominującym mechanizmem rynkowym, realizuje zadania interwencjonizmu rynkowego i strukturalnego (Tomczak, 2009). Oznacza to, że z jednej strony jej celem jest podtrzymywanie poziomu dochodów producentów rolnych, a $z$ drugiej strony ukierunkowana jest na zmiany struktury społeczno-ekonomicznej obszarów wiejskich. Chodzi tu o zróżnicowanie źródeł dochodów wiejskich gospodarstw domowych i racjonalne wykorzystanie zasobów materialnych, intelektualnych i społecznych. Z punktu widzenia rozwiązań instytucjonalnych polityka sektorowa jest kształtowana przez Ministerstwo Rolnictwa i Rozwoju Wsi, które odpowiada za podstawy prawne i kierunki strategiczne interwencjonizmu, a realizację zadań powierza się organizacjom powierniczym funkcjonującym jako państwowe osoby prawne ${ }^{4}$. Kluczową rolę $\mathrm{w}$ realizacji mechanizmów wsparcia odgrywają natomiast agencje rolne uczestniczące $\mathrm{w}$ przekazywaniu środków $\mathrm{z}$ budżetu unijnego i krajowego. Po integracji z Unią Europejską istnieją dwie agencje płatnicze wdrażające instrumenty Wspólnej Polityki Rolnej - Agencja Restrukturyzacji i Modernizacji Rolnictwa oraz Agencja Rynku Rolnego (Spychalski, 2008).

Obok instrumentów finansowych z budżetu unijnego ARiMR prowadzi preferencyjne kredytowanie rolnictwa i przetwórstwa rolno-spożywczego, dopłacając do oprocentowania wielu linii inwestycyjnych, obrotowych i związanych z klęskami żywiołowymi. Jest to istotny element pomocy krajowej dla rolników modernizujących swoje warsztaty produkcyjne i poprawiających płynność finansową w okresie zwiększonych zakupów środków produkcji. Z budżetu krajowego ARiMR finansuje także działalność podmiotów zajmujących się zbieraniem, przetwarzaniem na mączkę zwłok zwierzęcych bydła, owiec, kóz i świń, transportem lub spalaniem mączki.

Kolejnym ważnym obszarem interwencjonizmu państwowego w Polsce jest kształtowanie ustroju rolnego przez poprawę struktury obszarowej gospodarstw rolnych, przeciwdziałanie nadmiernej koncentracji nieruchomości rol-

\footnotetext{
${ }^{4}$ Najważniejsze podmioty to: Agencja Restrukturyzacji i Modernizacji Rolnictwa, Agencja Rynku Rolnego, Agencja Nieruchomości Rolnych, Kasa Rolniczego Ubezpieczenia Społecznego, Główny Inspektorat Weterynarii, Główny Inspektorat Ochrony Roślin i Nasiennictwa oraz Główny Inspektorat Jakości Handlowej Artykułów Rolno-Spożywczych. W Polsce rolnicy nie płacą podatku dochodowego (jedynie podatek rolny) oraz należą do oddzielnego systemu emerytalno-rentowego (KRUS). Wydatki na KRUS oznaczają dotacje dla Funduszu Emerytalno-Rentowego i utożsamiane są z wydatkami na rolnictwo. Mają charakter socjalny. Przywileje emerytalne rolników to w Europie stosunkowo rzadkie rozwiązanie i w dodatku stosowane przez coraz mniej krajów. Rolnicy mają przywileje emerytalne i płacą niższe składki niż reszta społeczeństwa tylko w Polsce, Austrii, Finlandii, Grecji i we Francji.
} 
nych oraz zapewnienie prowadzenia działalności rolniczej w gospodarstwach rolnych przez osoby o odpowiednich kwalifikacjach. Zadania te realizuje Agencja Nieruchomości Rolnych (poprzednio Agencja Własności Rolnej Skarbu Państwa) przez zagospodarowanie majątku ziemskiego byłych gospodarstw państwowych oraz nieruchomości Państwowego Funduszu Ziemi. Agencja stworzyła podstawy rynku ziemi rolniczej, szczególnie w północnej i zachodniej Polsce, gdzie podaż nieruchomości skarbowych jest duża ${ }^{5}$ (Maśniak, 2011). ANR realizuje także prace hodowlane i programy doskonalenia zasobu genetycznego roślin i zwierząt, wspierając w ten sposób postęp biologiczny w całym polskim rolnictwie. Uzupelnieniem tego jest Centrum Doradztwa Rolniczego, które odpowiada za upowszechnianie postępu biologicznego i technologicznego, a także wspiera działania informacyjno-szkoleniowe we wszystkich placówkach regionalnych i lokalnych (Spychalski, 2008).

Jeszcze innym elementem interwencjonizmu jest polityka rozwoju obszarów wiejskich, realizowana głównie $\mathrm{w}$ ramach aktywności jednostek samorządu terytorialnego. W polityce regionalnej wykorzystuje się działania inwestycyjne tworzące elementy infrastruktury technicznej i społecznej. Kreuje się przedsiębiorczość lokalną poprzez ulgi podatkowe, specjalne strefy ekonomiczne czy inkubatory przedsiębiorczości. W ramach strategii rozwoju lokalnego realizowane są projekty rozwoju kapitału ludzkiego i społecznego na obszarach wiejskich i przedsięwzięcia poprawiające jakość życia mieszkańców wsi.

Istotnym czynnikiem zmian modelu interwencjonizmu było przystąpienie Polski do Unii Europejskiej (1.05.2004 r.) i przejęcie dorobku Wspólnej Polityki Rolnej (Czubak, 2013). Od tego momentu agencje płatnicze odpowiadają za znaczną część mechanizmów interwencjonizmu. Agencja Rynku Rolnego realizuje zadania polityki rynkowej i stabilizuje zmienności cenowo-ilościowe na głównych rynkach surowców rolniczych. Agencja Restrukturyzacji i Modernizacji Rolnictwa przekazuje płatności bezpośrednie i wdraża programy polityki strukturalnej dla polskich obszarów wiejskich. Zakres i formy interwencjonizmu w rolnictwie i na obszarach wiejskich stanowią zatem wypadkową rozwiązań systemowych we Wspólnej Polityce Rolnej Unii Europejskiej, polskiego modelu polityki rolnej w procesie ewolucji oraz rozwiązań indywidualnych polityki regionalnej samorządu

\footnotetext{
${ }^{5}$ Obrót ziemią rolną w Polsce po 2016 r. http://www.raportrolny.pl/wiadomosci/item/4569obr\%C3\%B3t-ziemi\%C4\%85-roln\%C4\%85-w-polsce-po-2016-r.
} 
terytorialnego (Szymański, 2013) ${ }^{6}$.

\section{Aktualna skala finansowej pomocy}

Płatności bezpośrednie stanowią podstawowy instrument WPR i służą stabilizacji dochodów rolników. Płatności te od 2014 roku są przyznawane tzw. aktywnym rolnikom. Ograniczenie to ma na celu wyeliminowanie podmiotów, dla których działalność rolnicza nie stanowi głównego obszaru aktywności gospodarczej. Kluczową zmianą jest zastąpienie dotychczas funkcjonujących systemów płatności bezpośrednich SAPS i SPS systemem BPS (Basic Payment Scheme - system płatności podstawowej).

Nowy system płatności bezpośrednich na lata 2015-2020 składa się z dwóch podstawowych komponentów: obowiązkowego - takiego samego dla wszystkich państw Wspólnoty i dobrowolnego - wybieranego przez państwo członkowskie. Do obowiązkowych płatności bezpośrednich należą: jednolita płatność obszarowa (JPO), płatność na zazielenianie oraz płatność dla młodych rolników. W skład płatności dobrowolnych wchodzą natomiast: płatności dla małych gospodarstw, płatności związane z produkcją, płatności dodatkowe oraz przejściowe wsparcie krajowe. Nowy system wsparcia bezpośredniego dla rolników w Polsce składa się zatem z następujących elementów:

1. Jednolita płatność obszarowa.

2. Płatność za zazielenienie (greening).

3. Płatność dla młodych rolników.

4. Płatności związane z produkcją (bydła, krów, owiec, kóz, owoców miękkich tj.: truskawki i maliny, chmielu, roślin wysokobiałkowych, buraków cukrowych, ziemniaków skrobiowych, pomidorów, lnu i konopi włóknistych).

5. Płatność dodatkowa.

6. Płatności dla małych gospodarstw.

7. Przejściowe wsparcie krajowe (www.minrol.gov.pl, www.arimr.gov.pl).

\footnotetext{
${ }^{6}$ Zdaniem Szymańskiego (2013) duża część unijnych dopłat bezpośrednich do rolnictwa polskiego ma charakter socjalny, jednak w opinii tego autora, są one najtańszym, z makroekonomicznego punktu widzenia, sposobem finansowania potrzeb socjalnych ludności rolniczej, podobnie zresztą jak system emerytalny KRUS. Z drugiej strony żadna polityka nie zastąpi rynku w jego funkcji weryfikatora efektywności. W sytuacji niższej konkurencyjności cenowej rolnictwa europejskiego - z powodu wyższych wymogów środowiskowych i wyższych kosztów pracy - pojawia się dylemat ochrony rolnictwa europejskiego i utrzymania samowystarczalności żywnościowej. W opinii Szymańskiego (2013), Unia Europejska, Japonia, Korea Południowa i Stany Zjednoczone chronią swoje rolnictwo uznając, że światowe ceny produktów rolnych ukształtowane w długim okresie przez rynkowe nadwyżki rolne są zaniżone poprzez dumping ekonomiczny, socjalny i kursowy.
} 
W ramach tego systemu stosowana jest tzw. degresywność, polegająca na redukcji płatności o 100\% nadwyżki kwoty jednolitej płatności obszarowej ponad 150 tys. euro. Redukcją płatności objętych będzie ok. 150 gospodarstw (gospodarstwa o powierzchni ok. 1400 ha i większej). W Polsce nadal jest stosowany uproszczony system płatności bezpośrednich (co oznacza kontynuowanie stosowania jednolitej płatności obszarowej). Na płatność tę przeznaczono 44,7\% koperty krajowej (tj. ogółu środków unijnych przeznaczonych na płatności bezpośrednie w Polsce), czyli ponad 1,5 mld euro rocznie (stawka jednolitej płatności obszarowej wynosi ok. 110 euro/ha). Na płatność z tytułu praktyk rolniczych korzystnych dla klimatu i środowiska (płatność za zazielenienie) przeznaczono 30\% koperty krajowej, czyli ponad 1 mld euro rocznie (stawka płatności za zazielenienie wynosi ok. 74 euro/ha). Aby otrzymać płatności za zazielenienie, bezpośrednich, trzeba wprowadzić w swoim gospodarstwie następujące praktyki: dywersyfikację upraw, utrzymanie trwałych użytków zielonych (TUZ) i utrzymanie obszarów proekologicznych (tzw. EFA). Obowiązek dywersyfikacji upraw nie dotyczy gospodarstw o powierzchni gruntów ornych poniżej 10 ha, co oznacza, że ok. $83 \%$ rolników nie musi go wprowadzać. Gospodarstwa o powierzchni od 10 ha do 30 ha muszą wprowadzić co najmniej dwa rodzaje upraw, natomiast powyżej 30 ha gruntów ornych - minimum trzy rodzaje upraw. Do utrzymania obszarów proekologicznych (EFA) zobowiązane są gospodarstwa, w których powierzchnia gruntów ornych wynosi co najmniej 15 ha. Gospodarstwa o większej powierzchni muszą przeznaczyć 5\% swoich gruntów ornych na obszary proekologiczne, a od 2017 roku $-7 \%$.

Płatność dla młodych rolników to instrument ukierunkowany na ułatwianie zakładania działalności przez młodych (do 40 roku życia) rolników i dostosowań strukturalnych ich gospodarstw rolnych po rozpoczęciu działalności (nie dłużej niż 5 lat, licząc od dnia założenia gospodarstwa). Przeznaczono na tę płatność 2\% koperty krajowej (maksymalny odsetek dopuszczony przepisami unijnymi), czyli ponad $67 \mathrm{mln}$ euro rocznie. Dotacja ta ma postać płatności powierzchniowej, a jej stawka wynosi $25 \%$ średniej krajowej płatności na hektar, czyli ok. 62 euro/ha. Młodzi rolnicy mogą skorzystać z dwóch źródeł wsparcia, aby rozwijać swoje gospodarstwa. Oprócz pomocy z Programu Rozwoju Obszarów Wiejskich na lata 2014-2020, którą mogą otrzymać w formie bezzwrotnej premii wynoszącej 100 tys. zł (wypłacanej w dwóch ratach: $80 \%$ i $20 \%$ ), mogą także otrzymywać większe o $25 \%$ (czyli o ok. 62 euro/ha) dopłaty bezpośrednie niż ich starsi koledzy. Trzeba dodać, że maksymalna powierzchnia, do której młodzi rolnicy otrzymują powiększone dopłaty wynosi 50 ha. Rolnicy, którzy mają małe gospodarstwa mogą otrzymać bezzwrotną pomoc w wysokości 60 tys. zł na ich restrukturyzację ramach PROW 2014-2020. Jeżeli zdecydują się natomiast na prze- 
rwanie działalności rolniczej i sprzedanie swojego gospodarstwa, wówczas będzie im przysługiwać rekompensata w wysokości 120\% dopłat, które otrzymaliby do 2020 roku.

Celem płatności związanych z produkcją jest wsparcie sektorów, które mają szczególne znaczenie gospodarcze, środowiskowe lub społeczne, i które znajdują się w trudnej sytuacji, tj. sektorów bydła, krów, owiec, kóz, owoców miękkich (truskawki i maliny), chmielu, roślin wysokobiałkowych, buraków cukrowych, ziemniaków skrobiowych, pomidorów, lnu i konopi włóknistych. Na płatności związane z produkcją, we wszystkich sektorach łącznie, określono 15\% koperty krajowej (maksymalny odsetek dopuszczony przepisami unijnymi), tj. ponad $500 \mathrm{mln}$ euro rocznie.

Płatność dodatkowa przysługuje wszystkim rolnikom do gruntów mieszczących się w przedziale od trzeciego do trzydziestego ha. Na płatność dodatkową przeznaczono 8,3\% krajowej koperty finansowej (ok. $280 \mathrm{mln}$ euro rocznie). Stawka tej płatności wynosi ok. 41 euro/ha. Szacuje się, że płatność dodatkowa trafi do ok. 920 tys. gospodarstw, co stanowi ok. 68\% całkowitej liczby beneficjentów płatności bezpośrednich w Polsce.

Dzięki płatności dla małych gospodarstw realizowany jest w szczególności cel uproszczony, polegający na zwolnieniu rolników w nim uczestniczących z kontroli norm i wymogów zasady wzajemnej zgodności, a także z obowiązku stosowania praktyk zazielenienia. Do systemu dla małych gospodarstw rolnicy mogli przystąpić tylko w pierwszym roku jego stosowania, tj. w roku 2015. Rolników otrzymujących nie więcej niż 1250 euro na gospodarstwo włączono do systemu automatycznie. Wystąpienie z tego systemu będzie możliwe w dowolnym momencie, przy czym będzie to wiązało się z brakiem możliwości ponownego w nim udziału w kolejnych latach. Kwota płatności przysługująca danemu rolnikowi w ramach płatności dla małych gospodarstw to suma wszystkich płatności, do których otrzymania rolnik byłby uprawniony, gdyby pozostał w systemie standardowym. Szacuje się, że w systemie dla małych gospodarstw będzie uczestniczyć ok. 680 tys. gospodarstw, co stanowi prawie połowę całkowitej liczby beneficjentów płatności bezpośrednich w Polsce.

Przejściowym wsparciem krajowym objęto sektor tytoniu. Jest to jedyny dotychczas wspierany sektor, $\mathrm{w}$ odniesieniu do którego przepisy unijne nie dają możliwości stosowania płatności związanych z produkcją. Zgodnie z przepisami unijnymi, przejściowe wsparcie krajowe może być stosowane wyłącznie na warunkach, które były stosowane w odniesieniu do 2013 roku. Oznacza to, że wsparcie w sektorze tytoniu będzie mogło być stosowane jedynie w formie niezwiązanej z produkcją. W Polsce jest ok. 13 tys. beneficjentów tej płatności. 
W 2016 roku wydatki na rolnictwo, rozwój wsi i rynki rolne wyniosą 53,7 mld zł (będą niższe o ok. 3\% niż w 2015 r.), co stanowią 7,23\% wszystkich wydatków budżetowych. W gestii ministra rolnictwa znajdują się wydatki na rolnictwo, rozwój wsi oraz rynki rolne na kwotę 4,4 mld zł. W budżetach wojewodów wydatki na rolnictwo zapisano w kwocie ok. 1,08 mld zł. W rezerwie celowej na rolnictwo przewidziano $2,88 \mathrm{mld}$ zł oraz w innych częściach budżetu zapisano 280 tys. zł. Na dopłaty do ubezpieczeń roślin i zwierząt zaplanowano tyle samo co w ubiegłym roku, czyli $100 \mathrm{mln}$ zł. Na zwalczanie chorób zakaźnych (w tym na ASF) - $272 \mathrm{mln}$ zł (o 2,5\% więcej niż w 2015 r.), na program szklanka mleka przewidziano $119 \mathrm{mln}$ zł, a na dopłaty do materiału siewnego ponad $90 \mathrm{mln}$ zł. Dodatkowo na budżet rolny składają się: wydatki na KRUS - 18,2 mld zł, środki UE na finansowanie Wspólnej Polityki Rolnej - 26,6 mld zł oraz środki na pożyczki z Banku Gospodarstwa Krajowego dla jednostek samorządu terytorialnego 444 mln zł (www.minrol.gov.pl).

\section{Podsumowanie}

Przyrodnicze i ekonomiczne uwarunkowania produkcji rolnej implikują nieefektywną, w sensie Pareto, alokację czynników produkcji. W celu utrzymania zdolności sektora rolnego do reprodukcji rozszerzonej, konieczna jest dlatego aktywna polityka państwa. Przez określoną politykę rolną możliwe jest utrzymanie stabilnego wzrostu dochodów rolniczych w turbulentnym otoczeniu zewnętrznym. Interwencjonizm jest istotną cechą współczesnej polityki rolnej w większości państw na świecie.

Dyskusje zwolenników doktryny neokeynesowskiej (zakładającej stosowanie interwencjonizmu państwowego) ze zwolennikami doktryny neoliberalnej (opartej wyłącznie na prawach rynku) są zagorzałe i nieustające. Według zwolenników liberalnych teorii ekonomii, główną przyczyną przepaści cywilizacyjnej między krajami bogatymi i biednymi jest brak swobodnego przepływu towarów i kapitału. Przepaść tę pogłębia jeszcze bardziej subsydiowanie rolnictwa UE, USA, Korei czy Japonii, które ogranicza w ten sposób rozwój krajów najbiedniejszych.

W dotychczasowej filozofii dotowania rozwoju obszarów wiejskich dominującą rolę odgrywało subsydiowanie rolnictwa, zaś o wielu zmianach w jego kształcie decydowały głównie: wzrost produkcyjności (limity produkcji, obowiązkowe odłogowanie), negatywny wpływ rolnictwa na środowisko naturalne (cross-compliance), uwarunkowania w handlu międzynarodowym (płatności bezpośrednie oddzielone od produkcji), zmieniające się preferencje konsumentów (wystarczająca ilość bezpiecznej dla zdrowia 
żywności). Ten sposób myślenia i postrzegania funkcji WPR zmienia się jednak powoli.

Polski sektor rolny podlega zasadom WPR od 2004 roku. Oprócz dotacji unijnych, zachowano jednak wiele krajowych rozwiązań, które za zgodą Komisji Europejskiej mogą być nadal stosowne. Połączenie wszystkich form pomocy finansowej $\mathrm{z}$ udogodnieniami $\mathrm{w}$ systemie podatkowym, w systemie ubezpieczeń społecznych czy emerytalnym tworzy kompleksowy pakiet pomocowy dla rolnictwa.

\section{Bibliografia}

Agricultural Policy Monitoring and Evaluation (2013). OECD.

Czubak, W. (2013). Rozwój rolnictwa w Polsce z wykorzystaniem wybranych mechanizmów Wspólnej Polityki Rolnej Unii Europejskiej. Rozprawy Naukowe nr 458. Poznań: Wydawnictwo Uniwersytetu Przyrodniczego.

Czyżewski, A. (2003). Interwencjonizm w polityce krajów wysokorozwiniętych. W: A. Czyżewski (red.), Makroekonomiczne problemy agrobiznesu $w$ Polsce w okresie przedakcesyjnym (109-129). Poznań: Wydawnictwo AE.

Duczkowska-Małysz, K. (2013). Przyszłość polityki rozwoju obszarów wiejskich. Możliwe scenariusze. Dylematy $i$ wyzwania (ekspertyza). Pobrane z: www.mrr.gov.pl (6.02.2013).

Galbraith, J.K. (1991). Ekonomia w perspektywie. Krytyka historyczna. Warszawa: PWE.

Kocot, M. (2015). Uwagi o przyczynach interwencjonizmu w obszarze rolnictwa. Pobrane z: http://www.sbc.katowice.pl/Content/10182/kocot.pdf (19.05.2015).

Maśniak, J. (2011). Znaczenie polityki rolnej państwa w rozwoju rynku ziemi rolniczej w Polsce. Roczniki Nauk Rolniczych Seria G, 98 (3), 108-115.

Poczta, W. (2013). Gospodarstwa rolne w Polsce na tle gospodarstw Unii Europejskiej - wplyw WPR. Warszawa: GUS.

Rembisz, W. (2010). Krytyczna analiza podstaw i ewolucji interwencji w rolnictwie. Współczesna Ekonomia, 4.

Sobiecki, R. (2007). Globalizacja a funkcje polskiego rolnictwa. Warszawa: Oficyna Wydawnicza $\mathrm{SGH}$.

Sobiecki, R. (2015). Interwencjonizm w rolnictwie: dlaczego jest konieczny? Kwartalnik Nauk o Przedsiębiorstwie, 2, 38-46.

Spychalski, G. (2008). Działania interwencyjne w rolnictwie i na obszarach wiejskich w Polsce, Ekonomika i Organizacja Gospodarki Żywnościowej, 71, 43-47.

Stiglitz, J.E. (1987). Some Theoretical Aspects of Agricultural Policies, The World Bank Research Observer, 2 (1), 43-60.

Szymański, W. (2013). Racjonalność globalna a konkurencyjność ekonomiczno-społeczna rolnictwa. W: J.S. Zegar (red.), Z badań nad rolnictwem społecznie zrównoważonym (9-42). Raport Planu Wieloletniego nr 68. Warszawa: IERiGŻ-PIB.

Tomczak, F. (2009). Ewolucja wspólnej polityki rolnej UE i strategia rozwoju rolnictwa polskiego. Raport Planu Wieloletniego nr 125. Warszawa: IERiGŻ-PIB.

Van Huylenbroeck, G., Durand, G. (2007). Multifunctional agriculture: a new paradigm for European agriculture and rural development. Ashgate Publishing Ltd.

Wilkin, J. (2002), Interwencjonizm państwowy w rolnictwie: dlaczego był, jest i będzie. Biuletyn Informacyjny Agencji Rynku Rolnego, 2, 18-23.

Wilkin, J. (2015). Polskie rolnictwo opłaca się dotować. Pobrane z: http://finanse.wp.pl /kat,1034079,ti-tle,Wilkin-o-25-leciu-polskie-rolnictwo-oplaca-siedotowac,wid, 166 45065, wiadomosc. html?ticaid=116734 (31.05.2014). 
Wilkin, J. (2009). Ekonomia polityczna reform Wspólnej Polityki Rolnej, Gospodarka Narodowa, $1-2$.

www.arimr.gov.pl.

www.cairnsgroup.org.

www.minrol.gov.pl.

Ziętara, W. (2008). Uwagi o przyszłości polskich gospodarstw. W: M. Kłodziński (red.), Wyzwania przed obszarami wiejskimi i rolnictwem w perspektywie lat 2014-2020. Warszawa: IRWiR PAN.

Żmija, D. (2011), Dylematy dotyczące aktywnej roli państwa w obszarze rolnictwa. Zeszyty Naukowe Uniwersytetu Ekonomicznego w Krakowie, 863.

\section{Instruments of Farm-Support in Poland}

Keywords: polish farms, state aid, the Common Agricultural Policy, interventionism

Summary. The article is an explains interventionism in agricultural policy. In this publication the polish agricultural policy, which is realized recently, was shown. There is a description of Polish agricultural policy model and its evolution connected with the implementation of Common Agricultural Policy of European Union. Conclusion that agricultural sector occupies special position in economy was surmised, so its support is necessary.

Translated by Justyna Góral

\section{Cytowanie}

Góral, J. (2016). Instrumenty wspierania gospodarstw rolniczych w Polsce. Marketing i Zarządzanie, 2 (43), 57-69. 